ARTICLE

https://doi.org/10.1038/s41467-020-16460-w

\title{
Enabling safe aqueous lithium ion open batteries by suppressing oxygen reduction reaction
}

Long Chen ${ }^{1,3}$, Longsheng Cao ${ }^{1,3}$, Xiao Ji (10 ${ }^{1}$, Singyuk Hou ${ }^{1}$, Qin Li ${ }^{1}$, Ji Chen (1D ${ }^{1}$, Chongyin Yang (D) ${ }^{1}$, Nico Eidson ${ }^{1} \&$ Chunsheng Wang (1) $1,2 \otimes$

Due to the non-flammable nature of water-based electrolytes, aqueous lithium-ion batteries are resistant to catching fire. However, they are not immune to the risk of explosion, since the sealing structure adopted by current batteries limits the dissipation of heat and pressure within the cells. Here, we report a safe aqueous lithium-ion battery with an open configuration using water-in-salt electrolytes and aluminum oxide coated anodes. The design can inhibit the self-discharge by substantially suppressing the oxygen reduction reaction on lithiated anodes and enable good cycle performance over 1000 times. Our study may open a pathway towards safer lithium-ion battery designs.

\footnotetext{
${ }^{1}$ Department of Chemical and Biomolecular Engineering, University of Maryland, College Park, MD 20742, USA. ${ }^{2}$ Department of Chemistry and Biochemistry, University of Maryland, College Park, MD 20742, USA. ${ }^{3}$ These authors contributed equally: Long Chen, Longsheng Cao. ${ }^{凶}$ email: cswang@umd.edu
} 
T he safety of lithium-ion batteries (LIBs) has raised significant concerns in recent years due to several fire-related incidents ${ }^{1-3}$. The fully charged LIB consists of a highly energetic transition metal oxide cathode and a lithiated graphite anode in intimate contact with a flammable organic electrolyte. Any abuse by overcharging, external short-circuiting, or crushing can trigger spontaneous heat-generation. This exothermic event can result in thermal runaway, or even explosion due to high internal cell pressure producing fire and toxic gases. The thermal stability of batteries depends on the electrolyte's flammability and its ability to dissipate the heat and pressure. Currently, all commercial LIBs are in sealed configurations to protect the highly reactive electrodes and liquid electrolytes from reacting with the moisture and the reactive gases in the air, inherently limiting the dissipation of heat and pressure (Fig. 1a). Although many safety devices, such as safety vents, thermal fuses, circuit breakers, positive temperature coefficient elements, and shutdown separators, have been applied to LIBs and battery packs ${ }^{3}$, the fire and explosion risks of LIBs are still present. To make LIBs intrinsically safe, the LIBs' chemistry and configuration have to be changed.

At the chemistry level, the volatile, flammable, and toxic organic electrolytes in commercial LIBs should be replaced by non-flammable aqueous electrolytes ${ }^{4-8}$. However, the traditional non-flammable aqueous LIBs suffer from a low energy density due to the narrow electrochemical stability window of aqueous electrolytes 9 . The performance of aqueous LIBs is significantly impacted by the dissolved $\mathrm{O}_{2}$ in electrolytes from the air through the oxygen reduction reaction (ORR). Xia and coworkers ${ }^{10}$ have demonstrated that any discharged negative electrode in an aqueous LIB would react with $\mathrm{O}_{2}$, resulting in the marked capacity fading. Sealing cell can help to eliminate the $\mathrm{O}_{2}$ and can significantly improve the battery performance. But sealed aqueous LIBs still have the risk of thermal runaway and explosion when the internal cell pressure quickly rises, either by electrochemical water decomposition or uncontrolled high-temperature thermovaporization, as observed in sealed aqueous Ni-MH and VRLA (valve regulated lead acid) batteries. The battery's vents are not always able to prevent cell explosions because the pressure builds up from accelerated side reactions producing gas at a rate too fast for the safe operation of the safety valves, leading to the dangerous cell explosions. The sealed aqueous LIBs have to be replaced by an open configuration design due to their superior ability to dissipate heat and pressure. To our best knowledge, such open configuration aqueous LIBs have not been demonstrated yet. Recently, we developed a "water-in-salt electrolyte" (WiSE) that significantly reduced the $\mathrm{O}_{2}$ solubility in the electrolyte and expanded the electrochemical stability window of aqueous electrolytes from 1.5 to $>3.0 \mathrm{~V}$. The WiSE enabled the energy density of aqueous LIBs to be significantly enhanced from $75 \mathrm{Wh} \mathrm{kg}^{-1}$ to over $300 \mathrm{Wh} \mathrm{kg}^{-1}$ (on the material level) ${ }^{11-16}$. The uniqueness of WiSE has been extensively reviewed by Eftekhari ${ }^{9}$.

Here in this study, we report intrinsically safe LIBs with an open configuration. It is found that the $\mathrm{O}_{2}$ solubility markedly decreases in the electrolytes from $1.97 \mathrm{mg} \mathrm{L}^{-1}$ in $1 \mathrm{~m}$ "salt-inwater electrolytes" (SiWE) $\left(1 \mathrm{~m} \mathrm{Li}_{2} \mathrm{SO}_{4}\right)$ to $0.95 \mathrm{mg} \mathrm{L}^{-1}$ in $28 \mathrm{~m}$ WiSE (21 m LiTFSI $+8 \mathrm{~m}$ LiOTf, mol per kilogram), and further reduces to $0.19 \mathrm{mg} \mathrm{L}^{-1}$ in $63 \mathrm{~m}$ WiSE, significantly suppressing the ORR on lithiated anodes. The ORR on lithiated anodes can be further inhibited by coating 2.0-nm-thick aluminum oxide $\left(\mathrm{Al}_{2} \mathrm{O}_{3}\right)$ layer on anodes. Furthermore, the $28 \mathrm{~m} \mathrm{WiSE}$ can prevent water evaporation even at a high temperature of $\sim 100^{\circ} \mathrm{C}$ due to the strong hydrophilic property of the LiTFSI salt. The $\mathrm{LiMn}_{2} \mathrm{O}_{4} / / \mathrm{Al}_{2} \mathrm{O}_{3} @ \mathrm{LiTi}_{2}\left(\mathrm{PO}_{4}\right)_{3}$ open power cell with $28 \mathrm{~m}$ WiSE demonstrates an energy density of $62.4 \mathrm{Wh} \mathrm{kg}^{-1}$ and a stable cycle life of $>1000$ cycles. The $0.1 \mathrm{Ah} \mathrm{LiVPO}_{4} \mathrm{~F}_{/} / \mathrm{Al}_{2} \mathrm{O}_{3} @ \mathrm{Li}_{4} \mathrm{Ti}_{5} \mathrm{O}_{12}$ open pouch cell with $63 \mathrm{~m}$ WiSE $(42 \mathrm{~m}$ LiTFSI $+21 \mathrm{~m}$ $\mathrm{Pyr}_{13}$.TFSI) yield an energy density of $170 \mathrm{Wh} \mathrm{kg}^{-1}$ and a high energy efficiency of $92.8 \%$ for over 50 cycles.
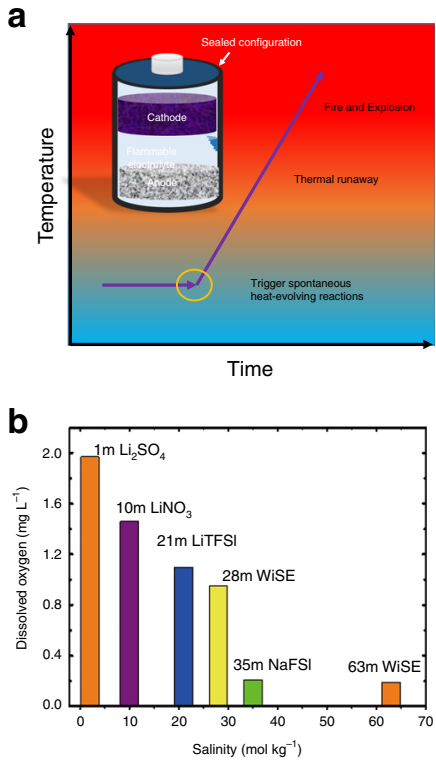
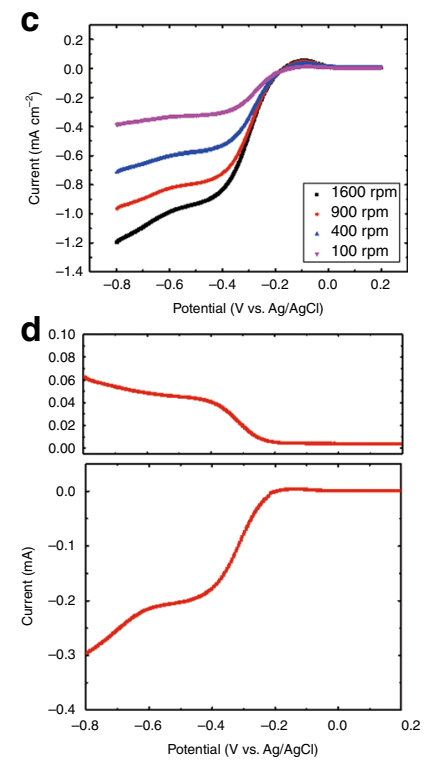
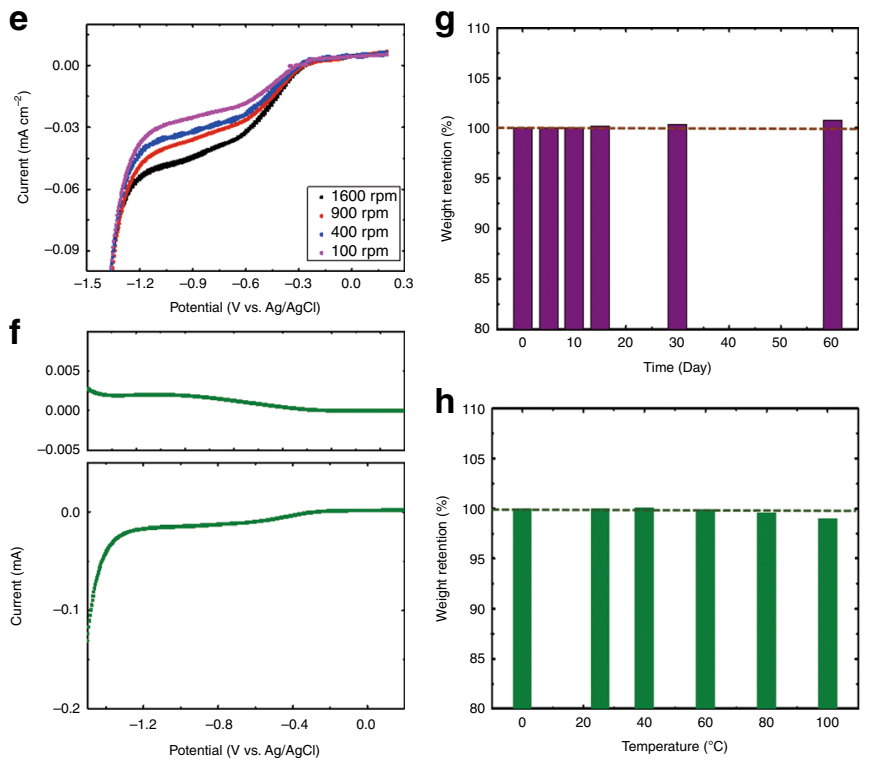

Fig. 1 The safety of commercial LIB and the oxygen reduction reaction (ORR) in the "water-in-salt electrolytes" (WiSE) and the "salt-in-water electrolytes" (SiWE). a Typical thermal runaway in a Li-ion cell with sealed-configuration. b Solubility of $\mathrm{O}_{2}$ in aqueous electrolytes. c Linear sweep voltammetry (LSV) of carbon black in the $\mathrm{O}_{2}$-saturated $1 \mathrm{~m} \mathrm{SiWE}$ at a scan rate of $10 \mathrm{mV} \mathrm{s}^{-1}$ with different rotating disk electrode (RDE) rotation rates. d LSV of carbon black in the $\mathrm{O}_{2}$-saturated $1 \mathrm{~m} \mathrm{SiWE}$ and the corresponding ring current for the oxidation of hydrogen peroxide at a scan rate of $10 \mathrm{mV} \mathrm{s}{ }^{-1}$ with a disc surface area of $0.2475 \mathrm{~cm}^{2}$, a rotating ring disk electrode (RRDE) collection efficiency of 0.37 , and an electrode rotation rate of 1600 rpm. e LSV of carbon black in the $\mathrm{O}_{2}$-saturated $28 \mathrm{~m} \mathrm{WiSE}$ at a scan rate of $10 \mathrm{mV} \mathrm{s}^{-1}$ with different RDE rotation rates. $\mathbf{f} \mathrm{LSV}$ of carbon black in the $\mathrm{O}_{2}$-saturated $28 \mathrm{~m}$ WiSE and the corresponding ring current for the oxidation of peroxide at a scan rate of $10 \mathrm{mV} \mathrm{s}^{-1}$ with a disc surface area of $0.2475 \mathrm{~cm}^{2}$, an RRDE collection efficiency of 0.37 , and an electrode rotation rate of $1600 \mathrm{rpm}$. $\mathbf{g}$ The mass retention of the $28 \mathrm{~m}$ WiSE in the air at room temperature with a relative humidity of $\sim 68 \%$. $\mathbf{h}$ The mass retention of the $28 \mathrm{~m} \mathrm{WiSE}$ at different temperatures for $30 \mathrm{~min}$. 


\section{Results}

WiSE enabled open configuration. The low $\mathrm{O}_{2}$ content in the $28 \mathrm{~m}$ WiSE reduces the ORR kinetics at the electrodes. In order to build an open aqueous battery, the ORR kinetics at the electrodes must be reduced. The gas solubility in a solvent can be largely reduced by increasing the salt concentration in the solvent ${ }^{17}$. Figure $1 \mathrm{~b}$ shows that the solubility of $\mathrm{O}_{2}$ in the water markedly decreases from $1.97 \mathrm{mg} \mathrm{L}^{-1}$ in the $1 \mathrm{~m} \mathrm{SiWE}$ to $0.95 \mathrm{mg} \mathrm{L}^{-1}$ in the $28 \mathrm{~m} \mathrm{WiSE}$, further down to $0.21 \mathrm{mg} \mathrm{L}^{-1}$ in the $35 \mathrm{~m}$ WiSE ( $35 \mathrm{~m} \mathrm{NaFSI}$ in $\mathrm{H}_{2} \mathrm{O}$ ), and even further to $0.19 \mathrm{mg} \mathrm{L}^{-1}$ in the $63 \mathrm{~m}$ WiSE. When an ionic salt is added to water, the dissolved ions will attract the water molecules due to ion solvation. The solvation of ions by water will reduce the affinity of dissolved non-polar $\mathrm{O}_{2}$ to water, thus reducing the solubility of $\mathrm{O}_{2}$ in water. The low $\mathrm{O}_{2}$ content in electrolytes reduces the ORR kinetics at the electrodes. Using carbon black as a model electrode (the most reactive component in conventional anodes), the ORR performances of carbon black in the $\mathrm{O}_{2}$-saturated $28 \mathrm{~m}$ WiSE and in the $\mathrm{O}_{2}$-saturated $1 \mathrm{~m} \mathrm{SiWE}$ were investigated using the RDE technique. The ORR kinetics on carbon black were significantly reduced with the increase of salt concentration in $\mathrm{O}_{2}$-saturated aqueous electrolytes, as demonstrated by three pieces of evidence in RDE measurements at $1600 \mathrm{rpm}$ (Fig. 1c, e): (1) The onset of the ORR potential at carbon black electrodes, where the reduction current increases sharply, $(-0.3 \mathrm{~V}$ vs. $\mathrm{Ag} / \mathrm{AgCl})$ in the $28 \mathrm{~m}$ WiSE (Fig. 1e) is more negative than the onset ORR potential $(-0.2 \mathrm{~V}$ vs. $\mathrm{Ag} / \mathrm{AgCl}$ ) in the $1 \mathrm{~m} \mathrm{SiWE}$ (Fig. 1c); (2) The limiting current of carbon black electrodes in the $28 \mathrm{~m} \mathrm{WiSE}\left(0.045 \mathrm{~mA} \mathrm{~cm}^{-2}\right)$ is only $4.5 \%$ of the limiting current $\left(1.0 \mathrm{~mA} \mathrm{~cm}^{-2}\right)$ in the $1 \mathrm{~m} \mathrm{SiWE}$; and (3) The half-wave potential $(-0.45 \mathrm{~V}$ vs. $\mathrm{Ag} / \mathrm{AgCl})$ of the ORR in the $28 \mathrm{~m}$ WiSE is much more negative than that $(-0.28 \mathrm{~V}$ vs. $\mathrm{Ag} / \mathrm{AgCl}$ ) in the $1 \mathrm{~m} \mathrm{SiWE}$. The much lower reduction current of the carbon black electrodes in the $\mathrm{N}_{2}$ saturated $28 \mathrm{~m}$ WiSE and $1 \mathrm{~m}$ SiWE (Supplementary Fig. 1) than those in the $\mathrm{O}_{2}$ saturated electrolytes at the same conditions (Fig. 1c, e) confirmed that the currents in Fig. 1c, e are attributed to the ORR.

The low diffusion coefficient in the $28 \mathrm{~m}$ WiSE further reduces the ORR kinetics on the electrodes. In addition to decreasing the $\mathrm{O}_{2}$ solubility, the high salt concentration also reduces the diffusion coefficients of $\mathrm{O}_{2}$ in the electrolytes. The diffusion coefficients for $\mathrm{O}_{2}$ in the $28 \mathrm{~m}$ WiSE and the $1 \mathrm{~m} \mathrm{SiWE}$ were calculated using the Koutecky-Levich (K-L) equation (Eq. 1).

$$
\frac{1}{|j|}=\frac{1}{\left|j_{\mathrm{k}}\right|}+\frac{1}{\left|j_{\mathrm{d}}\right|}=\frac{1}{\left|j_{\mathrm{k}}\right|}+\frac{1}{0.62 \mathrm{nF} D_{\mathrm{O}_{2}}^{2 / 3} C_{\mathrm{O}_{2}} \nu^{-1 / 6} \omega^{1 / 2}}
$$

Where $j$ is the measured current density; $j_{\mathrm{k}}$ is the kinetic current density; $F$ is the Faraday constant $\left(96485 \mathrm{C} \mathrm{mol}^{-1}\right) ; D_{\mathrm{O}_{2}}$ is the $\mathrm{O}_{2}$ diffusion coefficient in the electrolytes; $C_{\mathrm{O}_{2}}$ is the $\mathrm{O}_{2}$ saturation concentration in the electrolytes $\left(6.156 \times 10^{-5} \mathrm{~mol} \mathrm{~L}^{-1}\right.$ for the $1 \mathrm{~m} \mathrm{SiWE}$ and $2.968 \times 10^{-5} \mathrm{~mol} \mathrm{~L}^{-1}$ for the $28 \mathrm{~m} \mathrm{WiSE}$ ) (Fig. 1b); $v$ is the kinematic viscosity of the electrolyte that is obtained using the viscometer $\left(1.396 \mathrm{mPa} \mathrm{s}^{-1}\right.$ for the $1 \mathrm{~m} \mathrm{SiWE}$ and $202.44 \mathrm{mPa}$ $\mathrm{s}^{-1}$ for the $\left.28 \mathrm{~m} \mathrm{WiSE}\right)$; $\omega$ is the electrode rotation rate; and $n$ is the electron transfer number (for the $1 \mathrm{~m}$ SiWE, $n$ can be obtained via the RRDE test using Eq. 2).

$$
n=4-\frac{4 j_{\mathrm{r}}}{N\left|j_{\mathrm{d}}\right|+j_{\mathrm{r}}}
$$

Where $j_{\mathrm{r}}$ and $j_{\mathrm{d}}$ are the ring and the disk current, respectively, and $N$ is the collection efficiency (0.37). From the disk currents of the RRDE in Fig. 1d, the electron transfer number $(n)$ in the ORR in the $\mathrm{O}_{2}$-saturated $1 \mathrm{~m}$ SiWE was determined to be 2.4-2.6 (Supplementary Fig. 2a) using Eq. 2. This value corresponds to $71-80 \% \mathrm{H}_{2} \mathrm{O}_{2}$ (Supplementary Fig. 2b, calculated using Supplementary Eq. 1 in Supplementary Note 1) and $29-20 \% \mathrm{OH}^{-}$as the
ORR products. Hence, the diffusion coefficient of $\mathrm{O}_{2}\left(D_{\mathrm{O}_{2}}\right)$ in the $\mathrm{O}_{2}$-saturated $1 \mathrm{~m} \mathrm{SiWE}$ was determined to be $5.45 \times 10^{-5} \mathrm{~cm}^{2} \mathrm{~s}^{-1}$. In addition, the ORR products (both $\mathrm{H}_{2} \mathrm{O}_{2}$ and $\mathrm{OH}^{-}$) produced at carbon electrode surface quickly dissolve into the $1 \mathrm{~m} \mathrm{SiWE}$ and diffuse away from the electrode due to their high solubility and diffusivity, further accelerating the ORR kinetics ${ }^{18}$.

In contrast, the main ORR product on the carbon electrode in the $\mathrm{O}_{2}$-saturated $28 \mathrm{~m} \mathrm{WiSE}$ is $\mathrm{Li}_{2} \mathrm{O}_{2}$, which has been confirmed by the two clear $\mathrm{Li}_{2} \mathrm{O}_{2}$ peaks in the Raman spectrum of the discharged carbon electrode (Supplementary Fig. 3, Supplementary Note 2). It is consistent with previous reports in other WiSE ${ }^{19}$. However, limited $\mathrm{H}_{2} \mathrm{O}_{2}$ can still be monitored in the $\mathrm{O}_{2}$ saturated $28 \mathrm{~m}$ WiSE (Fig. 1f), suggesting that the $\mathrm{H}_{2} \mathrm{O}_{2}$ is possibly an intermediate in the ORR. The possible ORR pathway at the carbon electrode in the $28 \mathrm{~m}$ WiSE can be best expressed as follows:

$$
\begin{gathered}
\mathrm{O}_{2}+\mathrm{H}_{2} \mathrm{O}+2 \mathrm{e}^{-} \rightleftharpoons \mathrm{HO}_{2}^{-}+\mathrm{OH}^{-} \\
\mathrm{HO}_{2}^{-}+\mathrm{H}_{2} \mathrm{O} \rightleftharpoons \mathrm{H}_{2} \mathrm{O}_{2}+\mathrm{OH}^{-} \\
\mathrm{H}_{2} \mathrm{O}_{2}+2 \mathrm{OH}^{-}+2 \mathrm{Li}^{+} \rightleftharpoons \mathrm{Li}_{2} \mathrm{O}_{2}+2 \mathrm{H}_{2} \mathrm{O}
\end{gathered}
$$

The reaction mechanism suggests that $n$ for the ORR at the carbon electrode in the $28 \mathrm{~m} \mathrm{WiSE}$ should be 2 . The $D_{\mathrm{O}_{2}}$ in the $28 \mathrm{~m} \mathrm{WiSE}$ was determined from the K-L equation (Eq. 1) and the RDE data in Fig. 1e to be $1.54 \times 10^{-5} \mathrm{~cm}^{2} \mathrm{~s}^{-1}$. The $D_{\mathrm{O}_{2}}$ in the $28 \mathrm{~m}$ WiSE is less than the value $\left(5.45 \times 10^{-5} \mathrm{~cm}^{2} \mathrm{~s}^{-1}\right)$ in the $1 \mathrm{~m}$ SiWE, which further reduces the ORR kinetics at the carbon black electrode in the $28 \mathrm{~m}$ WiSE.

The formation of an insulating $\mathrm{Li}_{2} \mathrm{O}_{2}$ and $\mathrm{LiF}$ nano passivation layer on the anodes further reduces the ORR kinetics. Finally, the highly insulating $\mathrm{Li}_{2} \mathrm{O}_{2}$ at the carbon electrode does not dissolve in the $28 \mathrm{~m}$ WiSE but forms a nano passivation layer, which inhibits the ORR ${ }^{20-23}$. Moreover, an LiF-based solid-electrolyteinterphase (SEI) can also be formed on the anode from reduction of the LiTFSI in the WiSE at around -0.5 to $-0.3 \mathrm{~V}$ (vs. Ag/ $\mathrm{AgCl})^{5}$, further suppressing the ORR.

In addition to the capability of WiSE to reduce the ORR kinetics, it also prevents the water from evaporating. Fig. $1 g$ demonstrates the mass retention of the $28 \mathrm{~m} \mathrm{WiSE} \mathrm{during}$ exposure to the air with a relative humidity of $\sim 68 \%$ at room temperature. The $28 \mathrm{~m}$ WiSE retains the water content for over 60 days with only a slight mass intake of $0.8 \%$, indicating that the electrolyte actually absorbs moisture from the ambient air. Moreover, even when the $28 \mathrm{~m} \mathrm{WiSE}$ is exposed to the air at a high temperature of $100{ }^{\circ} \mathrm{C}$ (boiling point of water) for $30 \mathrm{~min}$, the mass retention of this electrolyte is still over 99\% (Fig. 1h), which indicates that only trace water will evaporate at this high operating temperature. The high stability of the TFSI anion in the aqueous electrolyte at different $\mathrm{pH}$ values for 100 days at various temperatures has been shown in a previous study ${ }^{24}$. The $28 \mathrm{~m}$ WiSE is stable in the open-cell configuration within a wide temperature window for a long period of time. In summary, the ORR kinetics at the carbon black electrodes in the $1 \mathrm{~m} \mathrm{SiWE}$ and the $28 \mathrm{~m}$ WiSE are schematically shown in Fig. 2. The ORR at the carbon black electrode in the $28 \mathrm{~m}$ WiSE is significantly reduced due to the low solubility of $\mathrm{O}_{2}$, sluggish $\mathrm{O}_{2}$ diffusion, and the formation of $\mathrm{Li}_{2} \mathrm{O}_{2}$ and $\mathrm{LiF}$ nano passivation layer on the electrode. In addition, the high stability of the $28 \mathrm{~m}$ WiSE in the air also enables the $28 \mathrm{~m}$ WiSE-based cells to be fabricated in an open configuration.

$\mathrm{Al}_{2} \mathrm{O}_{3}$ suppressing the $\mathrm{ORR}$ at the anode surface. The $\mathrm{LiF}-\mathrm{Li}_{2} \mathrm{O}_{2}$ nano passivation layer on the anode displays selfhealing capability in the $28 \mathrm{~m}$ WiSE and can suppress the ORR at 
a

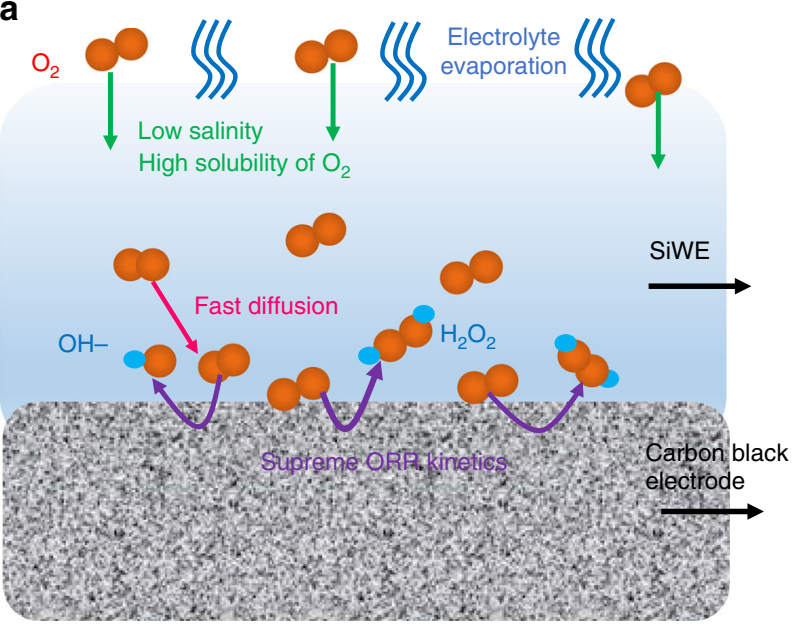

b

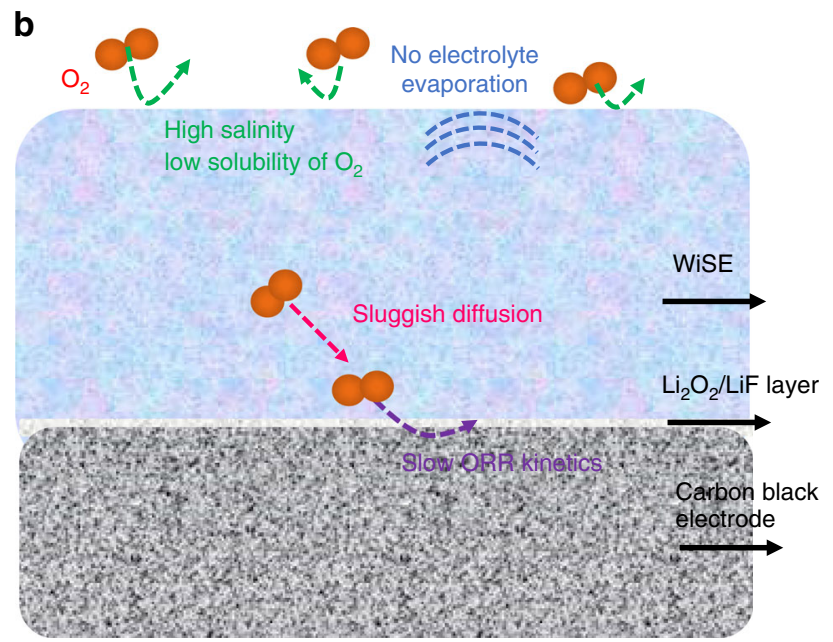

Fig. 2 Schematic of the ORR at the carbon black electrodes in the SiWE and the WiSE. a Schematic of the ORR in the $1 \mathrm{~m}$ SiWE. b Schematic of the ORR in the $28 \mathrm{~m}$ WiSE.

the anode surface, thus reducing the cell self-discharge rate and extending the cell cycle life. However, the formation of this passivation layer on the anode consumes the salts and the Li-ions from the lithiated cathode. To suppress the ORR during the initial passivation layer formation process, an $\mathrm{Al}_{2} \mathrm{O}_{3}$ nano-layer was coated on the electrode using ALD to generate an artificial SEI layer prior to cell construction.

The $\mathrm{O}_{2}$ adsorption and the subsequent ORR on the $\mathrm{Al}_{2} \mathrm{O}_{3}$ surface were investigated. Figure $3 \mathrm{a}, \mathrm{b}$ delivers the different charge densities of the $\mathrm{O}_{2}$ adsorbed on the $\mathrm{Al}_{2} \mathrm{O}_{3}$ slab. The corresponding adsorption energies $\left(E_{\mathrm{ad}}\right)$ were calculated using Eq. 6:

$$
E_{\text {ad }}=E_{\left(\mathrm{Al}_{2} \mathrm{O}_{3}+\mathrm{O}_{2}\right)}-E_{\left(\mathrm{Al}_{2} \mathrm{O}_{3}\right)}-E_{\left(\mathrm{O}_{2}\right)}
$$

Where the $E_{\left(\mathrm{Al}_{2} \mathrm{O}_{3}+\mathrm{O}_{2}\right)}$ is the energy of $\mathrm{O}_{2}$ adsorbed by the $\mathrm{Al}_{2} \mathrm{O}_{3}$ slab; $E_{\left(\mathrm{Al}_{2} \mathrm{O}_{3}\right)}$ and $E_{\left(\mathrm{O}_{2}\right)}$ are the energy of the $\mathrm{Al}_{2} \mathrm{O}_{3}$ slab and the $\mathrm{O}_{2}$, respectively. The more negative adsorption energy indicates the stronger $\mathrm{O}_{2}$ adsorption. The typical adsorption energies of the $\mathrm{O}_{2}$ intermediates on $\mathrm{Pt}, \mathrm{Ni}, \mathrm{Pd}, \mathrm{Cu}$, and $\operatorname{Ir}(111)$ metals surface are $-0.72,-1.67,-1.01,-0.56$, and $-1.27 \mathrm{eV}$, respectively 25,26 . The binding energy of $\mathrm{O}_{2}$ on the $\mathrm{O}^{-}$and the Al-surface of $\mathrm{Al}_{2} \mathrm{O}_{3}$ are around 0.05 and $-0.18 \mathrm{eV}$, demonstrating the weak interaction between the $\mathrm{O}_{2}$ and the $\mathrm{Al}_{2} \mathrm{O}_{3}$ surface and the difficulty in the dissociation of the $\mathrm{O}_{2}$ on the $\mathrm{Al}_{2} \mathrm{O}_{3}$ surface.

The RDE curves in Fig. 3c, d confirm that the ORR kinetics at the $\mathrm{Al}_{2} \mathrm{O}_{3}$ surface are much slower than the ORR kinetics at the carbon back electrode. Figure $3 \mathrm{c}$ shows the LSV of the carbon black and the $\mathrm{Al}_{2} \mathrm{O}_{3}$ in the $\mathrm{O}_{2}$-saturated $1 \mathrm{~m} \mathrm{SiWE}$, the ORR onset potential of the ORR at the $\mathrm{Al}_{2} \mathrm{O}_{3}$ surface is $0.1 \mathrm{~V}$ lower than at the carbon black surface. The limiting current density at $1600 \mathrm{rpm}$ at the $\mathrm{Al}_{2} \mathrm{O}_{3}$ surface $\left(0.107 \mathrm{~mA} \mathrm{~cm}^{-2}\right)$ is only $1 / 8$ of that $\left(0.85 \mathrm{~mA} \mathrm{~cm}^{-2}\right)$ at the carbon black surface. Similarly, the $\mathrm{Al}_{2} \mathrm{O}_{3}$ also reduces the ORR current in the $28 \mathrm{~m}$ WiSE (Fig. 3d). The onset potential of the ORR at the $\mathrm{Al}_{2} \mathrm{O}_{3}$ surface is also $0.2 \mathrm{~V}$ lower than that at the carbon black surface in the $28 \mathrm{~m}$ WiSE (Fig. 3d). In addition, the $\mathrm{Al}_{2} \mathrm{O}_{3}$ has a fast Li-ion diffusivity ${ }^{27}$ and the ALD- $\mathrm{Al}_{2} \mathrm{O}_{3}$ coating technology has been widely used in industry.

WiSE and $\mathrm{Al}_{2} \mathrm{O}_{3}$ enabling low self-discharge anodes. After assessing the ORR kinetics in the presence of WiSE and $\mathrm{Al}_{2} \mathrm{O}_{3}$ coating, further measurements with a model anode are needed to confirm the above results. As the lithiation/delithiation potential of $\mathrm{LiTi}_{2}\left(\mathrm{PO}_{4}\right)_{3}$ anode is within the electrochemical stability windows of both the $1 \mathrm{~m} \mathrm{SiWE}$ and the $28 \mathrm{~m}$ WiSE, the $\mathrm{LiTi}_{2}\left(\mathrm{PO}_{4}\right)_{3}$ anode was used as a model anode to compare the self-discharge behaviors in the $1 \mathrm{~m} \mathrm{SiWE}$ and the $28 \mathrm{~m}$ WiSE. The Coulombic efficiency of the $\mathrm{LiTi}_{2}\left(\mathrm{PO}_{4}\right)_{3}$ in the $1 \mathrm{~m} \mathrm{SiWE}$ at the current density of $0.5 \mathrm{~A} \mathrm{~g}^{-1}$ is only $89 \%$ (Fig. 4a) and no delithiation capacity is available for the fully lithiated $\mathrm{Li}_{3} \mathrm{Ti}_{2}\left(\mathrm{PO}_{4}\right)_{3}$ after $10 \mathrm{~h}$ of relaxation at open-circuit in an opencell (Fig. 4b). The open-circuit potential changed from the fully lithiated potential of $-0.7 \mathrm{~V}$ to the fully dilithiated potential of $+0.2 \mathrm{~V}$ during $10 \mathrm{~h}$ (Fig. 4c). Therefore, the fully lithiated $\mathrm{Li}_{3} \mathrm{Ti}_{2}\left(\mathrm{PO}_{4}\right)_{3}$ in the $1 \mathrm{~m}$ SiWE has completely self-discharged to be $\operatorname{LiTi}_{2}\left(\mathrm{PO}_{4}\right)_{3}$ after $10 \mathrm{~h}$ rest in an open-cell configuration. Supplementary Fig. 4 and Supplementary Note 3 confirm the ORR at the $\operatorname{LiTi}_{2}\left(\mathrm{PO}_{4}\right)_{3}$ electrode. Supplementary Fig. 5 and Supplementary Note 4 further confirm the effects of the dissolved $\mathrm{O}_{2}$ in the electrolytes on the self-discharge performance of the lithiated $\mathrm{Li}_{3} \mathrm{Ti}_{2}\left(\mathrm{PO}_{4}\right)_{3}$, the open-circuit potential changed to $+0.2 \mathrm{~V}$ after only a half hour in a pure $\mathrm{O}_{2}$ atmosphere, while its lithiated potential can be maintained for $50 \mathrm{~h}$ without potential increase when the cell was in the absence of $\mathrm{O}_{2}$ (in a $\mathrm{N}_{2}$ atmosphere). Therefore, it can be concluded that the self-discharge of the fully lithiated $\mathrm{Li}_{3} \mathrm{Ti}_{2}\left(\mathrm{PO}_{4}\right)_{3}$ in the $1 \mathrm{~m}$ SiWE open-cell is proceeds through the following ORR pathway:

$$
\begin{gathered}
\mathrm{O}_{2}+4 \mathrm{e}^{-}+2 \mathrm{H}_{2} \mathrm{O} \rightleftharpoons 4 \mathrm{OH}^{-} \\
\mathrm{O}_{2}+2 \mathrm{e}^{-}+2 \mathrm{H}_{2} \mathrm{O} \rightleftharpoons \mathrm{H}_{2} \mathrm{O}_{2}+2 \mathrm{OH}^{-} \\
\mathrm{Li}_{3} \mathrm{Ti}_{2}\left(\mathrm{PO}_{4}\right)_{3} \rightleftharpoons \mathrm{LiTi}_{2}\left(\mathrm{PO}_{4}\right)_{3}+2 \mathrm{Li}^{+}+2 \mathrm{e}^{-}
\end{gathered}
$$

In an open-cell configuration, the dissolved $\mathrm{O}_{2}$ in the electrolyte receives electrons from the $\mathrm{Li}_{3} \mathrm{Ti}_{2}\left(\mathrm{PO}_{4}\right)_{3}$ and is reduced into $\mathrm{OH}^{-}$ or $\mathrm{H}_{2} \mathrm{O}_{2}$. As expected, when the $\mathrm{Al}_{2} \mathrm{O}_{3}$ nano-layer coated $\mathrm{LiTi}_{2}\left(\mathrm{PO}_{4}\right)_{3}$ electrode (Supplementary Figs. 6 and 7) is charged/ discharged in the $28 \mathrm{~m}$ WiSE, the Coulombic efficiency markedly increases to $99.9 \%$ (Fig. $4 \mathrm{~d}$ ). The capacity retention of the fully lithiated $\mathrm{Li}_{3} \mathrm{Ti}_{2}\left(\mathrm{PO}_{4}\right)_{3}$ after $10 \mathrm{~h}$ rest in an open-cell configuration still reaches a high value of $>97 \%$ (Fig. 4e). Also, the open-circuit potential is maintained at $-0.5 \mathrm{~V}$ (Fig. $4 \mathrm{f}$ ) due to the ORR on the lithiated $\mathrm{Al}_{2} \mathrm{O}_{3} @ \mathrm{Li}_{3} \mathrm{Ti}_{2}\left(\mathrm{PO}_{4}\right)_{3}$ being significantly inhibited. To further confirm the high ORR suppression capability of the WiSE, a moderate salinity concentration electrolyte of $10 \mathrm{~m}$ LiTFSI and a high concentration of $30 \mathrm{~m}$ WiSE $\left(28 \mathrm{~m} \mathrm{ZnCl}_{2}+2 \mathrm{~m} \mathrm{LiCl}\right)$ were also selected to evaluate the self-discharge of the lithiated $\mathrm{Al}_{2} \mathrm{O}_{3} @ \mathrm{Li}_{3} \mathrm{Ti}_{2}\left(\mathrm{PO}_{4}\right)_{3}$ anodes. As shown in Supplementary Fig. 8 and Supplementary Note 5 , only $52 \%$ of the discharge capacity 
a

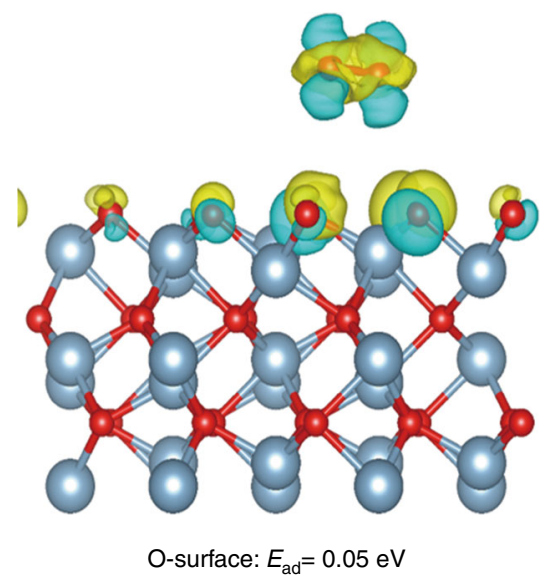

c

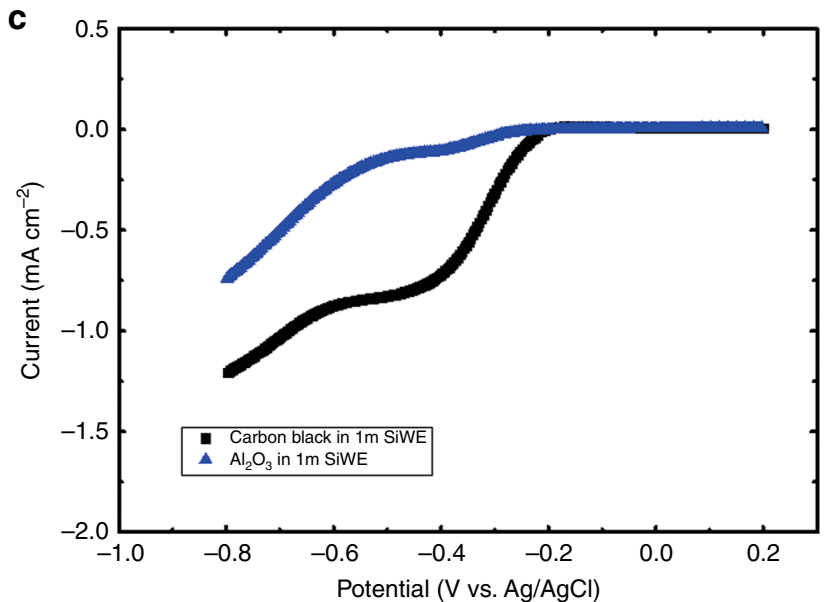

b

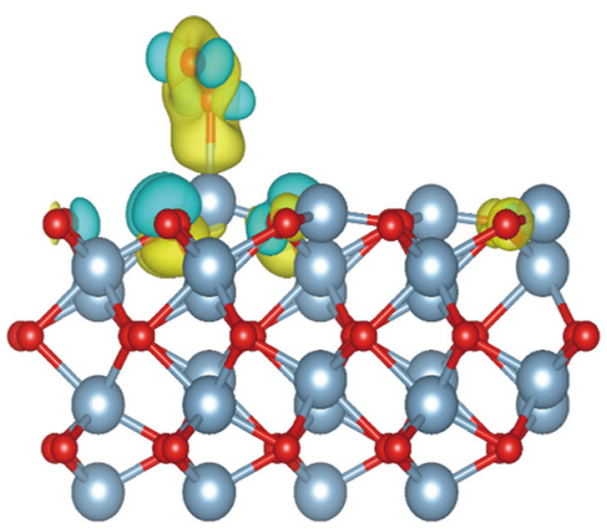

Al-surface: $E_{\mathrm{ad}}=-0.18 \mathrm{eV}$

d

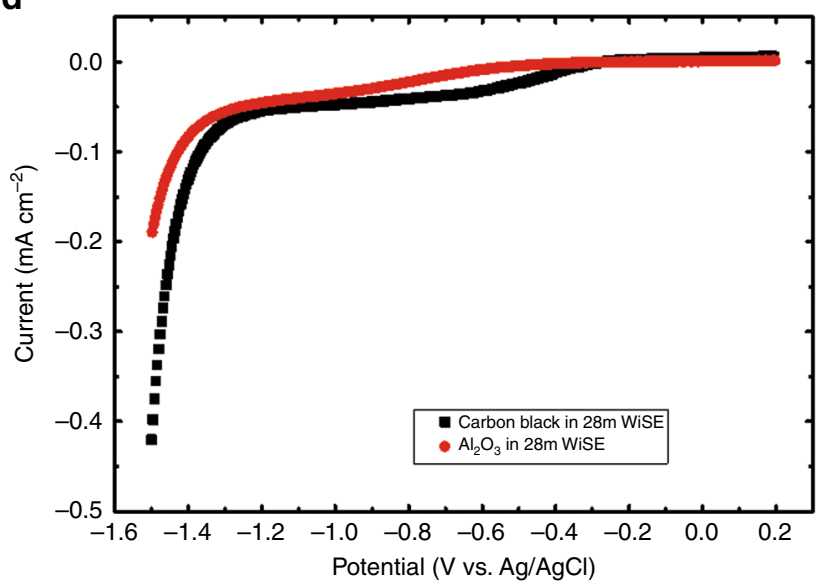

Fig. 3 The effect of the $\mathbf{A l}_{\mathbf{2}} \mathbf{O}_{\mathbf{3}}$ coating on the ORR at the electrode. Different charge densities of $\mathrm{O}_{2}$ adsorbed on the O-surface (a) and Al-surface (b) of $\mathrm{Al}_{2} \mathrm{O}_{3}$. Red and blue spheres represent $\mathrm{O}$ and $\mathrm{Al}$ atoms, respectively, the corresponding adsorption energies ( $\left.E_{\text {ad }}\right)$ are listed below. c LSV of the carbon black and $\mathrm{Al}_{2} \mathrm{O}_{3}$ in the $\mathrm{O}_{2}$-saturated $1 \mathrm{~m} \mathrm{SiWE}$ at a scan rate of $10 \mathrm{mV} \mathrm{s}^{-1}$ with a rotation rate of $1600 \mathrm{rpm}$; $\mathbf{d} \mathrm{LSV}_{\text {of }}$ the carbon black and $\mathrm{Al}_{2} \mathrm{O}_{3}$ in the $\mathrm{O}_{2}-$ saturated $28 \mathrm{~m} \mathrm{WiSE}$ at a scan rate of $10 \mathrm{mV} \mathrm{s}^{-1}$ with a rotation rate of $1600 \mathrm{rpm}$. The carbon black and $\mathrm{Al}_{2} \mathrm{O}_{3}$ loading on the $\mathrm{RDE}$ are $20 \mu \mathrm{g}$.

remains after $10 \mathrm{~h}$ in the $10 \mathrm{~m}$ LiTFSI electrolyte, whereas in the $30 \mathrm{~m}$ WiSE, the discharged electrode retains over $98 \%$ of the initial capacity after a $10 \mathrm{~h}$ rest and it maintains over $96 \%$ of the initial capacity after $24 \mathrm{~h}$ in an open-cell configuration (Supplementary Figs. 9 and 10).

Electrochemical performance of safe WiSE full open cells. Based on the successfully inhibition of the ORR at the lithiated anode, a full open-cell was designed and fabricated. As the charge/discharge potentials of the $\mathrm{LiMn}_{2} \mathrm{O}_{4}$ cathode and the $\mathrm{LiTi}_{2}\left(\mathrm{PO}_{4}\right)_{3}$ anode are within the electrochemical stability window of both the $28 \mathrm{~m} \mathrm{WiSE}$ and the $1 \mathrm{~m} \mathrm{SiWE}$, the electrochemical performances of the $\mathrm{LiMn}_{2} \mathrm{O}_{4} / / \mathrm{Al}_{2} \mathrm{O}_{3} @ \mathrm{LiTi}_{2}\left(\mathrm{PO}_{4}\right)_{3}$ open-cell in the $28 \mathrm{~m} \mathrm{WiSE}$ and the $\mathrm{LiMn}_{2} \mathrm{O}_{4} / / \mathrm{LiTi}_{2}\left(\mathrm{PO}_{4}\right)_{3}$ opencell in the $1 \mathrm{~m}$ SiWE were compared. The $\mathrm{LiMn}_{2} \mathrm{O}_{4} / / \mathrm{Al}_{2} \mathrm{O}_{3} @ \mathrm{Li}$ $\mathrm{Ti}_{2}\left(\mathrm{PO}_{4}\right)_{3}$ open-cell in the $28 \mathrm{~m}$ WiSE delivered a capacity of $62.4 \mathrm{Wh} \mathrm{kg}^{-1}$ (of total mass of the anode and the cathode) at a rate of $5 \mathrm{C}$ (Fig. 5a) and displayed a high Coulombic efficiency of over $99.9 \%$ with a stable cycle life of $>1000$ cycles (Fig. 5b, c). In sharp contrast, the capacity of the $\mathrm{LiMn}_{2} \mathrm{O}_{4} / / \mathrm{LiTi}_{2}\left(\mathrm{PO}_{4}\right)_{3}$ opencell in the $1 \mathrm{~m}$ SiWE decreased markedly due to the poor Coulombic efficiency (Supplementary Fig. 11, Fig. 5b, c). Selfdischarge is a key issue for all batteries, Supplementary Fig. 12 and Supplementary Note 6 demonstrate that the fully charged $\mathrm{LiMn}_{2} \mathrm{O}_{4} / / \mathrm{LiTi}_{2}\left(\mathrm{PO}_{4}\right)_{3}$ open-cell with the $1 \mathrm{~m}$ SiWE was fully self-discharged by the $\mathrm{O}_{2}$ in the air after $10 \mathrm{~h}$ of rest under ambient conditions. The self-discharge performance of the $\mathrm{LiMn}_{2} \mathrm{O}_{4} / / \mathrm{Al}_{2} \mathrm{O}_{3} @ \mathrm{LiTi}_{2}\left(\mathrm{PO}_{4}\right)_{3}$ open-cell in the $28 \mathrm{~m}$ WiSE was measured after resting for $10 \mathrm{~h}$ and the fully charged open-cell maintained $96.8 \%$ of the initial charged capacity (Supplementary Fig. 13). The capacity retention is still larger than $90 \%$ after 15 days of rest (Supplementary Fig. 14). Furthermore, the charging of the $\mathrm{LiMn}_{2} \mathrm{O}_{4} / / \mathrm{Al}_{2} \mathrm{O}_{3} @ \mathrm{LiTi}_{2}\left(\mathrm{PO}_{4}\right)_{3}$ open cell with a constant capacity can minimize the effect of self-discharge on cycling stability. The constant capacity charge protocol enables the $\mathrm{LiMn}_{2} \mathrm{O}_{4} / / \mathrm{Al}_{2} \mathrm{O}_{3} @ \mathrm{LiTi}_{2}\left(\mathrm{PO}_{4}\right)_{3}$ open-cell in the $28 \mathrm{~m}$ WiSE to maintain the same discharge capacity for 100 cycles at a low rate of $1 \mathrm{C}$, which results in the Coulombic efficiency of the $\mathrm{LiMn}_{2} \mathrm{O}_{4} / / \mathrm{Al}_{2} \mathrm{O}_{3} @ \mathrm{LiTi}_{2}\left(\mathrm{PO}_{4}\right)_{3}$ open power cell at $1 \mathrm{C}$ reaching $>99.7 \%$ (Supplementary Fig. 13b). Even at a low rate of $0.2 \mathrm{C}$, the $\mathrm{LiMn}_{2} \mathrm{O}_{4} / / \mathrm{Al}_{2} \mathrm{O}_{3} @ \mathrm{LiTi}_{2}\left(\mathrm{PO}_{4}\right)_{3}$ open cell shows a stable discharge capacity for 35 cycles under the constant charge capacity protocol (Supplementary Fig. 15).

To further enhance the cell energy density, a $2.7 \mathrm{~V}, 0.1 \mathrm{Ah}$ $\mathrm{LiVPO}_{4} \mathrm{~F} / / \mathrm{Al}_{2} \mathrm{O}_{3} @ \mathrm{Li}_{4} \mathrm{Ti}_{5} \mathrm{O}_{12}$ open pouch demo cell was fabricated (Supplementary Fig. 16) using a high voltage $\mathrm{LiVPO}_{4} \mathrm{~F}$ cathode and evaluated in the $63 \mathrm{~m}$ WiSE. The $63 \mathrm{~m}$ WiSE has a low $\mathrm{O}_{2}$ concentration $\left(0.19 \mathrm{mg} \mathrm{L}^{-1}\right)$ and wide electrochemical potential window of $>3.15 \mathrm{~V}\left(1.76 \mathrm{~V}-4.91 \mathrm{~V}\right.$ vs. $\mathrm{Li}^{+} / \mathrm{Li}$ ) (Supplementary Fig. 17, Supplementary Note 7). The $\mathrm{LiVPO}_{4} \mathrm{~F} / / \mathrm{Al}_{2} \mathrm{O}_{3} @ \mathrm{Li}_{4} \mathrm{Ti}_{5} \mathrm{O}_{12}$ open pouch cell in the $63 \mathrm{~m}$ WiSE was cycled at a rate of $0.2 \mathrm{C}$ and provided $170 \mathrm{Wh} \mathrm{kg}^{-1}$ (based on of the total mass of the 

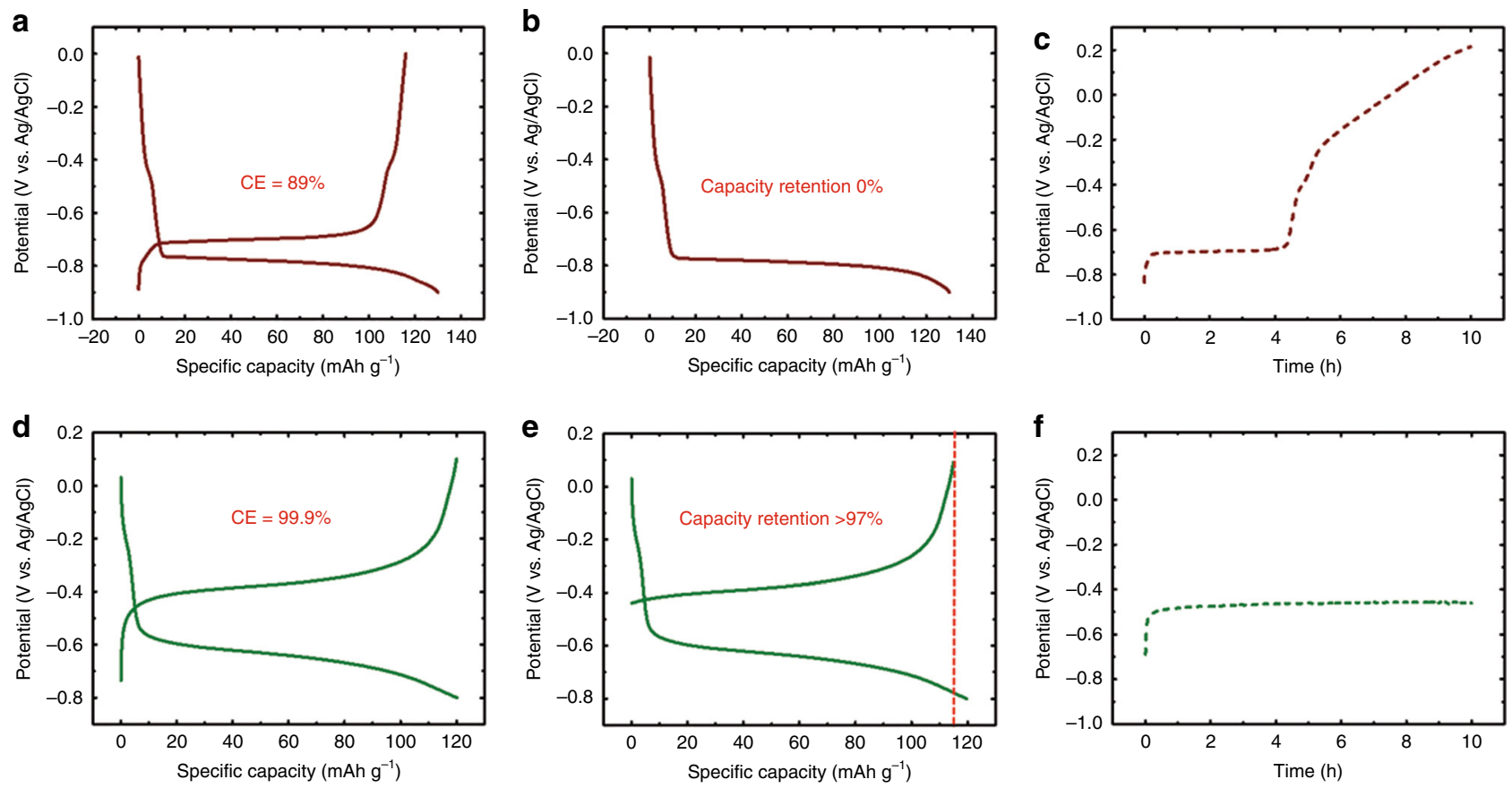

Fig. 4 Effects of the ORR on the self-discharge of the lithiated $\mathrm{Li}_{3} \mathrm{Ti}_{\mathbf{2}}\left(\mathrm{PO}_{\mathbf{4}}\right)_{\mathbf{3}}$ electrodes in a three-electrodes open-cell configuration. a the charge/ discharge curves of the $\mathrm{LiTi}_{2}\left(\mathrm{PO}_{4}\right)_{3}$ electrode in the $1 \mathrm{~m} \mathrm{SiWE}$ at the current density of $0.5 \mathrm{Ag}^{-1}$. $\mathbf{b}$ The lithiation potential profile of the LiTi $2\left(\mathrm{PO}_{4}\right)_{3}$ electrode in the $1 \mathrm{~m} \mathrm{SiWE}$ at the current density of $0.5 \mathrm{~A} \mathrm{~g}^{-1}$ prior to self-discharge evaluation. $\mathbf{c}$ The open-circuit potential curve of the discharged $\mathrm{LiTi}_{2}\left(\mathrm{PO}_{4}\right)_{3}$ in the $1 \mathrm{~m}$ SiWE over $10 \mathrm{~h}$ of relaxation at open-circuit. $\mathbf{d}$ The charge/discharge curves of the $\mathrm{Al}_{2} \mathrm{O}_{3} @ \mathrm{LiTi}_{2}\left(\mathrm{PO}_{4}\right)_{3}$ electrode in the $28 \mathrm{~m}$ WiSE at the current density of $0.5 \mathrm{~A} \mathrm{~g}^{-1}$. e The lithiation potential profile and the subsequent delithiation profile of the $\mathrm{Al}_{2} \mathrm{O}_{3} @ \mathrm{LiTi}_{2}\left(\mathrm{PO}_{4}\right)_{3}$ electrode at the current density of $0.5 \mathrm{~A} \mathrm{~g}^{-1}$ in the $28 \mathrm{~m} \mathrm{WiSE}$ after $10 \mathrm{~h}$ relaxation at open-circuit. $\mathbf{f}$ The open-circuit potential profile of the lithiated $\mathrm{Al}_{2} \mathrm{O}_{3} @ \mathrm{Li}_{3} \mathrm{Ti}_{2}\left(\mathrm{PO}_{4}\right)_{3}$ electrode in the $28 \mathrm{~m}$ WiSE over $10 \mathrm{~h}$ of relaxation at open-circuit. These tests were conducted in an open-cell configuration with exposure to the ambient air.

anode and the cathode) (Supplementary Fig. 18, Supplementary Note 8 and Fig. 5d). The cell achieved over 50 cycles with a Coulombic efficiency of $96.8 \%$ (Fig. 5e).

Energy efficiency is another critical factor for new battery systems $^{28,29}$. We have calculated the energy efficiency of the $\mathrm{LiMn}{ }_{2} \mathrm{O}_{4} / / \mathrm{Al}_{2} \mathrm{O}_{3} @ \mathrm{LiTi}_{2}\left(\mathrm{PO}_{4}\right)_{3}$ open-cell at the rate of $1 \mathrm{C}$ and found it to be $90 \%$ (Supplementary Fig. 13C). The energy efficiency of the $\mathrm{LiVPO}_{4} \mathrm{~F} / / \mathrm{Al}_{2} \mathrm{O}_{3} @ \mathrm{Li}_{4} \mathrm{Ti}_{5} \mathrm{O}_{12}$ open pouch cell, cycled at $0.2 \mathrm{C}$, (Fig. $5 \mathrm{e}$ ) is as high as $92.8 \%$, which is comparable with the value (in the range of $86-98 \%$ ) of commercial LIBs 29,30 . Therefore, the open-cell configuration developed here can satisfy the demand of the market.

To address the potential electrolyte leakage issue in the opencell design, we added PVA (Poly(vinyl alcohol)) into the $28 \mathrm{~m}$ WiSE to form a gel electrolyte. The gel electrolyte can flow when the temperature is increased to $95^{\circ} \mathrm{C}$ in order to facilitate battery assembly. When the electrolyte is cooled back to room temperature it forms a solid phase that can eliminate any electrolyte leakage. Supplementary Fig. 19 and Supplementary Note 9 show that the $28 \mathrm{~m}$ gel WiSE do not flow at room temperature. As shown in Supplementary Fig. 19b, c, the $\mathrm{LiMn} \mathrm{O}_{4} / / \mathrm{Al}_{2} \mathrm{O}_{3} @ \mathrm{LiTi}_{2}\left(\mathrm{PO}_{4}\right)_{3}$ open pouch cell with the $28 \mathrm{~m}$ gel WiSE achieved similar electrochemical performance as the cell with the liquid $28 \mathrm{~m}$ WiSE. Supplementary Fig. 20, Supplementary Note 10 and Supplementary Movie 1 show that the $\mathrm{LiMn} \mathrm{O}_{4} / / \mathrm{Al}_{2} \mathrm{O}_{3} @ \mathrm{LiTi}_{2}\left(\mathrm{PO}_{4}\right)_{3}$ open pouch cell with the $28 \mathrm{~m}$ gel WiSE was able to stably power a fan without any electrolyte leakage, even after the pouch cell was cut with scissors.

This aqueous open-cell configuration is a universal design that can also be used in other aqueous batteries. For example, the $35 \mathrm{~m}$ WiSE also effectively suppressed the ORR at the discharged electrode, which enabled the intercalated $\mathrm{Na}_{3} \mathrm{Ti}_{2}\left(\mathrm{PO}_{4}\right)_{3}$ electrode in an open-cell configuration to maintain over $98.5 \%$ of the initial capacity after resting at open-circuit for $10 \mathrm{~h}$ (Supplementary Fig. 21). In addition, the $30 \mathrm{~m}$ WiSE also effectively suppressed the ORR at the $\mathrm{Zn}$ anode, as demonstrated by the much higher Coulombic efficiency (87.5\%) for the $\mathrm{Zn}$ plating and stripping in the $30 \mathrm{~m}$ WiSE than in the $5 \mathrm{~m} \mathrm{ZnCl}_{2}$ SiWE (53\%) (Supplementary Fig. 22). The open-cell configuration has several other advantages: (1) some safety devices are not necessary within the cell such as an additional ventilation system; (2) they can be charged at a high voltage setting and high rate; and (3) they have a much lower up-front cost by removing the safety devices and sealing process.

\section{Discussion}

The non-flammable aqueous batteries still carry the risk of explosion due to rapidly increasing internal pressure caused by side reaction gaseous products and thermal runaway. The WiSE can effectively suppress the electrolyte evaporation and the ORR reaction at the discharged anode. The ORR at the anode can be further suppressed by coating an $\mathrm{Al}_{2} \mathrm{O}_{3}$ nano-layer, which enables the batteries to operate in an open configuration. The $\mathrm{LiMn}_{2} \mathrm{O}_{4} / /$ $\mathrm{Al}_{2} \mathrm{O}_{3} @ \mathrm{LiTi}_{2}\left(\mathrm{PO}_{4}\right)_{3}$ open power cell achieves a stable cycle life of over 1000 cycles with a low self-discharge rate $(90 \%$ capacity retention after 15 days). The $2.7 \mathrm{~V} \mathrm{LiVPO}{ }_{4} \mathrm{~F} / / \mathrm{Al}_{2} \mathrm{O}_{3} @ \mathrm{Li}_{4} \mathrm{Ti}_{5} \mathrm{O}_{12}$ open pouch cell achieves a high energy density of $170 \mathrm{Wh} \mathrm{kg}^{-1}$. The open configuration design provides enhanced resistance to thermal runaway and high-pressure explosion that can markedly improves the safety of LIBs.

\section{Methods}

Materials synthesis. $\mathrm{LiMn}_{2} \mathrm{O}_{4}$ and $\mathrm{Li}_{4} \mathrm{Ti}_{5} \mathrm{O}_{12}$ were purchased from $\mathrm{MTI}$. $\mathrm{LiVPO}_{4} \mathrm{~F}$ was supplied by ALeees. To synthesize the carbon-coated $\mathrm{LiTi}_{2}\left(\mathrm{PO}_{4}\right)_{3}$. At first, $100 \mathrm{~mL} 2 \mathrm{wt} \%$ poly-vinyl-alcohol (PVA) aqueous solution was prepared, then $\mathrm{Li}_{2} \mathrm{CO}_{3}, \mathrm{NH}_{4} \mathrm{H}_{2} \mathrm{PO}_{4}$ and $\mathrm{TiO}_{2}$ were blended with it. A white solid product was 
a
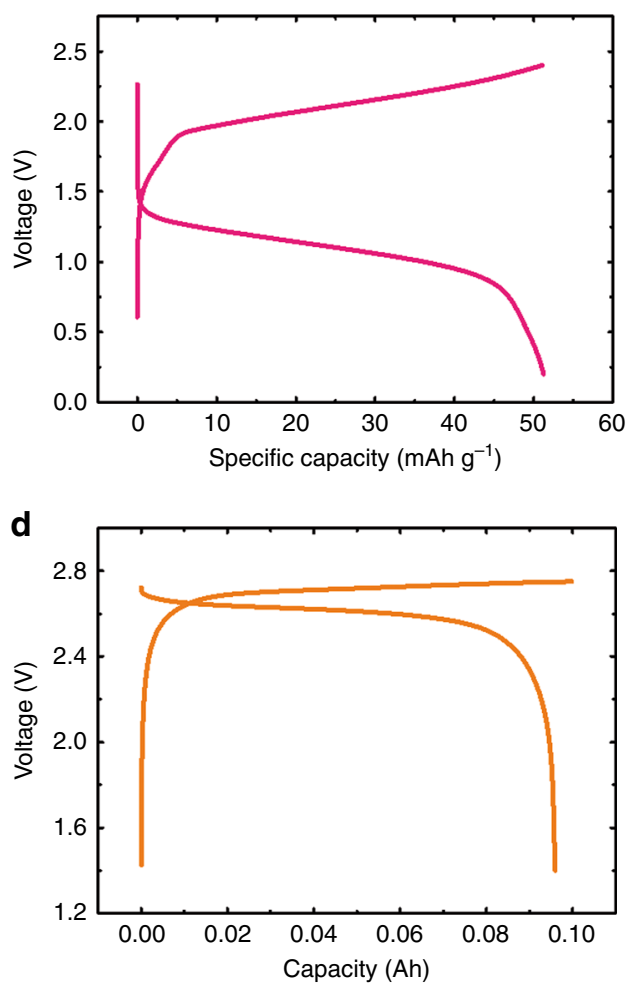

b
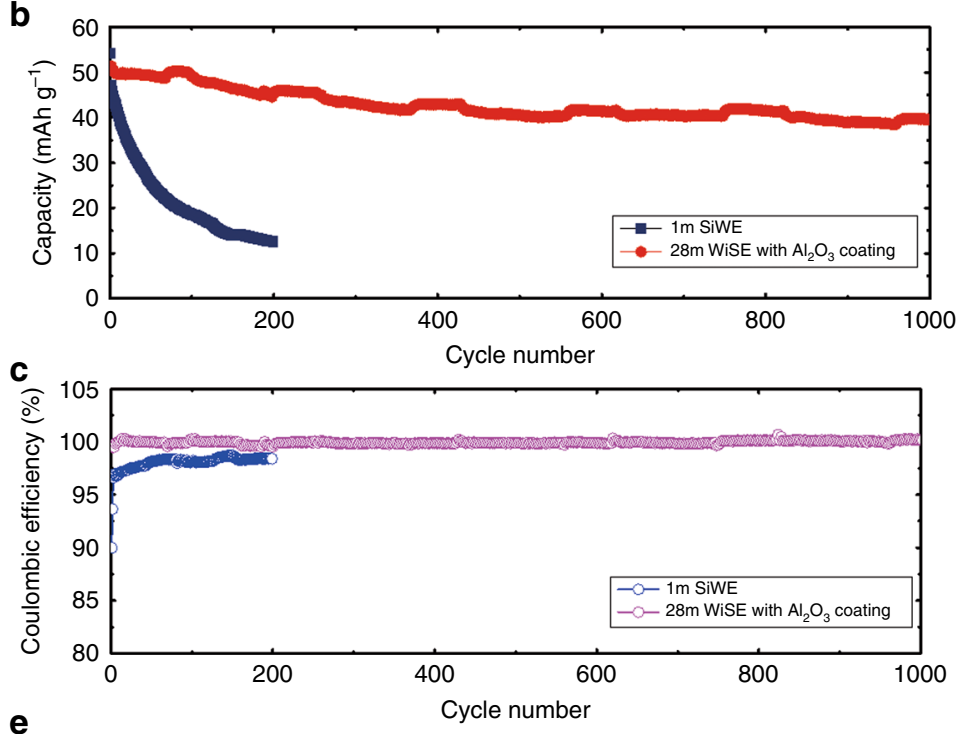

Fig. 5 Electrochemical performance of the WiSE full open cells. a The charge/discharge curves of the $\mathrm{LiMn}_{2} \mathrm{O}_{4} / / \mathrm{Al}_{2} \mathrm{O}_{3} @ \mathrm{LiTi}_{2}\left(\mathrm{PO}_{4}\right)_{3}$ open-cell with the $28 \mathrm{~m}$ WiSE at a rate of $5 \mathrm{C}$. b The cycling performance of the $\mathrm{LiMn}_{2} \mathrm{O}_{4} / / \mathrm{Al}_{2} \mathrm{O}_{3} @ \mathrm{LiTi}_{2}\left(\mathrm{PO}_{4}\right)_{3}$ open-cell with the $28 \mathrm{~m}$ WiSE at a rate of $5 \mathrm{C}$. c The Coulombic efficiency of the $\mathrm{LiMn}_{2} \mathrm{O}_{4} / / \mathrm{Al}_{2} \mathrm{O}_{3} @ \mathrm{LiTi}_{2}\left(\mathrm{PO}_{4}\right)_{3}$ open-cell with the $28 \mathrm{~m}$ WiSE at a rate of $5 \mathrm{C}$. $\mathbf{d}$ The charge/discharge curves of the demo $\mathrm{LiVPO}_{4} \mathrm{~F} / / \mathrm{Al}_{2} \mathrm{O}_{3} @ \mathrm{Li}_{4} \mathrm{Ti}_{5} \mathrm{O}_{12}$ open pouch cell with the $63 \mathrm{~m}$ WiSE and a constant charge capacity of $0.1 \mathrm{Ah}$ at a rate of $0.2 \mathrm{C}$. e The cycling performance and the energy efficiency of the demo $\mathrm{LiVPO}_{4} \mathrm{~F} / / \mathrm{Al}_{2} \mathrm{O}_{3} @ \mathrm{Li}_{4} \mathrm{Ti}_{5} \mathrm{O}_{12}$ open pouch cell with the $63 \mathrm{~m}$ WiSE and a constant charge capacity of $0.1 \mathrm{Ah}$ at a rate of $0.2 \mathrm{C}$.

formed when the water was evaporated after heating at $80{ }^{\circ} \mathrm{C}$ with continuous stirring. The product was heated at $900{ }^{\circ} \mathrm{C}$ for $10 \mathrm{~h}$ at a temperature increasing rate of $5^{\circ} \mathrm{C} \mathrm{min}^{-1}$ under the protection of $\mathrm{N}_{2}$ flow. During the heat-treatment process, it was in a porcelain boat, and the tube furnace was applied. Thermal decomposition vapor-deposition technology was applied to coat carbon on the surface of $\mathrm{LiTi}_{2}\left(\mathrm{PO}_{4}\right)_{3}$. The as-prepared $\mathrm{LiTi}_{2}\left(\mathrm{PO}_{4}\right)_{3}$ was placed in a tube furnace and further heated at $700{ }^{\circ} \mathrm{C}$ for $2 \mathrm{~h}$, during which, the toluene vapor was carried by $\mathrm{N}_{2}$ through the tube. The flow rate of $\mathrm{N}_{2}$ is $1 \mathrm{~L} \mathrm{~min}^{-1}$. After that, the product was further heated at $900{ }^{\circ} \mathrm{C}$ for $2 \mathrm{~h}$ under the protection of $\mathrm{N}_{2}$ without toluene.

Atomic layer deposition. The electrodes were coated with $\mathrm{Al}_{2} \mathrm{O}_{3}$ nano-layer using the atomic layer deposition (ALD) equipment (Beneq TFS 500). The carrier gas was high-purity $\mathrm{N}_{2}$ with a temperature of $150{ }^{\circ} \mathrm{C}$. 20 precursor pulse cycles of $\mathrm{ALD}-\mathrm{Al}_{2} \mathrm{O}_{3}$ were applied to form 2-nm-thickness layer on the surface of electrodes. During each cycle, alternating trimethylaluminum $\left(4 \mathrm{~s}, \mathrm{Al}\right.$ precursor) and $\mathrm{H}_{2} \mathrm{O}(4 \mathrm{~s}$, oxygen precursor) flows were separated by flows of $\mathrm{N}_{2}$ ( $4 \mathrm{~s}$ for the carrier gas, $10 \mathrm{~s}$ for the cleaning gas).

Electrode preparation and electrochemical measurements. The working electrodes were prepared by mixing active materials $\left(\mathrm{LiMn}_{2} \mathrm{O}_{4}, \mathrm{LiTi}_{2}\left(\mathrm{PO}_{4}\right)_{3}, \mathrm{LiVPO}_{4} \mathrm{~F}\right.$, or $\mathrm{Li}_{4} \mathrm{Ti}_{5} \mathrm{O}_{12}$ ), conductive materials (carbon black, $\mathrm{CB}$ ), and binder PTFE (polytetrafluoroethylene) in a weight ratio of 90:5:5 of active materials/CB/PTFE, then compressing them onto a stainless steel grid $\left(\mathrm{LiMn}_{2} \mathrm{O}_{4}\right.$ and $\left.\mathrm{LiTi}_{2}\left(\mathrm{PO}_{4}\right)_{3}\right)$, Ti grid $\left(\mathrm{LiVPO}{ }_{4} \mathrm{~F}\right)$, or $\mathrm{Al}$ grid $\left(\mathrm{Li}_{4} \mathrm{Ti}_{5} \mathrm{O}_{12}\right)$ at $10 \mathrm{MPa}$. The linear sweep voltammetry (LSV) tests were performed using a three-electrodes cell, in which, the activated carbon was used as the counter electrode, the $\mathrm{Ag} / \mathrm{AgCl}$ electrode was used as the reference electrode. The LSV measurements were carried out on a CHI660B electrochemical workstation. The galvanostatic charge/discharge tests of anodes were performed using a three-electrodes cell, in which, the activated carbon was used as the counter electrode, the $\mathrm{Ag} / \mathrm{AgCl}$ electrode was used as the reference electrode. The galvanostatic charge/discharge of full cells were performed using the Arbin electrochemical working station.

The carbon black, $\mathrm{Al}_{2} \mathrm{O}_{3}$ (nano particles form Sigma) and carbon-coated $\mathrm{LiTi}_{2}\left(\mathrm{PO}_{4}\right)_{3}$ inks were prepared as follows: (1) the active materials $(5 \mathrm{mg})$ was dispersed in a mixture of isopropanol $(2.5 \mathrm{~mL})$ and Nafion solution $(20 \mu \mathrm{L}) ;(2)$ treat the mixture with ultra-sonication for $30 \mathrm{~min}$. After that, the ink $(10 \mu \mathrm{L})$ was deposited on a glassy carbon disk electrode (RDE or RRDE) and evaporated the solvent in air at room temperature. The electrochemical measurements were performed in a three-electrodes cell at ambient temperature. The RDE or RRDE was used as the working electrode, a platinum electrode as the counter electrode, and $\mathrm{Ag} / \mathrm{AgCl}$ as the reference electrode. The data was recorded using a Gamry interface 1000 .

Materials characterizations. Raman measurements were carried out by a Horiba Jobin Yvon Labram Aramis using a $532 \mathrm{~nm}$ diode-pumped solid-state laser, attenuated to give $\sim 900 \mu \mathrm{W}$ power at the sample surface. Scanning electron microscopy (SEM) measurements were carried out by Hitachi SU-70 analytical SEM (Japan). Viscosity measurements were carried out using a CANNON-FENSKE viscometer. The surface chemistry of the electrodes after ALD coating was examined by XPS with a Kratos Axis 165 spectrometer. XPS data was collected using a monochromated $\mathrm{Al} \mathrm{Ka} \mathrm{X}$-ray source $(1486.7 \mathrm{eV})$. The working pressure of the chamber was lower than $6.6 \times 10^{-9} \mathrm{~Pa}$. All reported binding energy values were caLIBrated to the $\mathrm{C} 1 s$ peak at $284.8 \mathrm{eV}$.

Computational details. All density functional theory (DFT) calculations ${ }^{31,32}$ were performed using a Vienna Ab Initio Simulation Package (VASP) ${ }^{33}$ with projector augmented wave (PAW) method ${ }^{34}$. The exchange-correlation energy is described by the functional Perderw, Burke, and Ernzerhof (PBE) version of the generalized gradient approximation $(\mathrm{GGA})^{35}$. And the energy cut-off for the plane wave basis is $520 \mathrm{eV}$. A vacuum layer of $12 \AA$ was used for all calculated models. The energy of $\mathrm{O}_{2}$ is obtained from the Materials Project ${ }^{36}$. Visualization of the structures are made by VESTA ${ }^{37}$.

\section{Data availability}

The data that support the plots within this paper and other findings of this study are available from the corresponding authors upon reasonable request. 
Received: 17 February 2020; Accepted: 26 April 2020;

Published online: 26 May 2020

\section{References}

1. Deng, J., Bae, C., Marcicki, J., Masias, A. \& Miller, T. Safety modelling and testing of lithium-ion batteries in electrified vehicles. Nat. Energy 3, 261-266 (2018).

2. Doughty, D. \& Roth, E. P. A general discussion of Li ion battery safety. Electrochem. Soc. Interface 21, 37-44 (2012).

3. Balakrishnan, P. G., Ramesh, R. \& Kumar, T. P. Safety mechanisms in lithiumion batteries. J. Power Sources 155, 401-414 (2006).

4. Li, W., Dahn, J. R. \& Wainwright, D. Rechargeable lithium batteries with aqueous electrolytes. Science 264, 1115-1118 (1994).

5. Suo, L. et al. "Water-in-salt" electrolyte enables high-voltage aqueous lithiumion chemistries. Science 350, 938-943 (2015).

6. $\mathrm{Xu}, \mathrm{K}$. Nonaqueous liquid electrolytes for lithium-based rechargeable batteries. Chem. Rev. 104, 4303-4417 (2004).

7. $\mathrm{Xu}, \mathrm{K}$. Electrolytes and interphases in Li-ion batteries and beyond. Chem. Rev. 114, 11503-11618 (2014)

8. Pasta, M., Wessells, C. D., Huggins, R. A. \& Cui, Y. A high-rate and long cycle life aqueous electrolyte battery for grid-scale energy storage. Nat. Commun. 3, 1149 (2012).

9. Eftekhari, A. High-energy aqueous lithium batteries. Adv. Energy Mater. 8, 1801156 (2018).

10. Luo, J., Cui, W., He, P. \& Xia, Y. Raising the cycling stability of aqueous lithium-ion batteries by eliminating oxygen in the electrolyte. Nat. Chem. 2 , 760-765 (2010).

11. Yang, C. et al. 4.0 V aqueous Li-ion batteries. Joule 1, 122-132 (2017).

12. Suo, L. et al. Advanced high-voltage aqueous lithium-ion battery enabled by 'water-in-bisalt' electrolyte. Angew. Chem. Int. Ed. 55, 7136-7141 (2016).

13. Yamada, Y. et al. Hydrate-melt electrolytes for high-energy-density aqueous batteries. Nat. Energy 1, 16129 (2016).

14. Yang, C. et al. Unique aqueous Li-ion/sulfur chemistry with high energy density and reversibility. PNAS 114, 6197-6202 (2017).

15. Wang, F. et al. Highly reversible zinc metal anode for aqueous batteries. Nat. Mater. 17, 543-549 (2018).

16. Yang, C. et al. Aqueous Li-ion battery enabled by halogen conversion-intercalation chemistry in graphite. Nature 569, 245-250 (2019).

17. Whipple, G. C. \& Whipple, M. C. Solubility of oxygen in sea water. J. Am. Chem. Soc. 33, 362-365 (1911).

18. Suo, L. et al. How solid-electrolyte interphase forms in aqueous electrolytes. $J$. Am. Chem. Soc. 139, 18670-18680 (2017).

19. Dong, Q. et al. Cathodically stable $\mathrm{Li}^{-} \mathrm{O}_{2}$ battery operations using water-in-salt electrolyte. Chem 4, 1-14 (2018).

20. Das, S. K. et al. High energy lithium-oxygen batteries-transport barriers and thermodynamics. Energy Environ. Sci. 5, 8927-8931 (2012).

21. Lu, Y. \& Yang-Shao, H. Probing the reaction kinetics of the charge reactions of nonaqueous $\mathrm{Li}_{-} \mathrm{O}_{2}$ batteries. J. Phys. Chem. Lett. 4, 93-99 (2013).

22. Viswanathan, V. et al. Electrical conductivity in $\mathrm{Li}_{2} \mathrm{O}_{2}$ and its role in determining capacity limitations in non-aqueous $\mathrm{Li}^{-} \mathrm{O}_{2}$ batteries. J. Chem. Phys. 135, 214704 (2011).

23. Viswanathan, V. et al. Li-O2 kinetic overpotentials: Tafel plots from experiment and first principles theory. J. Phys. Chem. Lett. 4, 556-560 (2013).

24. Lux, S. F. et al. LiTFSI stability in water and its possible use in aqueous lithium-ion batteries: $\mathrm{pH}$ dependency, electrochemical window and temperature stability. J. Electrochem. Soc. 160, A1694-A1700 (2013).

25. Xu, Y. \& Mavrikakisa, M. Adsorption and dissociation of $\mathrm{O}_{2}$ on $\operatorname{Ir}(111)$. J. Chem. Phys. 116, 10846 (2002).

26. Choi, Y., Lin, M. C. \& Liu, M. Computational study on the catalytic mechanism of oxygen reduction on $\mathrm{La}_{0.5} \mathrm{Sr}_{0.5} \mathrm{MnO}_{3}$ in solid oxide fuel cells Angew. Chem. Int. Ed. 46, 7214-7219 (2007).

27. Jung, $\mathrm{S}$. \& Han, $\mathrm{Y}$. How do $\mathrm{Li}$ atoms pass through the $\mathrm{Al} 2 \mathrm{O} 3$ coating layer during lithiation in Li-ion batteries? J. Phys. Chem. Lett. 4, 2681-2685 (2013).

28. Eftekhari, A. The mechanism of ultrafast supercapacitors. J. Mater. Chem. A 6 , 2866-2876 (2018).
29. Eftekhari, A. Energy efficiency: a critically important but neglected factor in battery research. Sustain. Energy Fuels 1, 2053-2060 (2017).

30. Omar, N. et al. Rechargeable energy storage systems for plug-in hybrid electric vehicles-assessment of electrical characteristics. Energies 5, 2952-2988 (2012).

31. Hohenberg, P. \& Kohn, W. Inhomogeneous electron gas. Phys. Rev. 136, B864 (1964).

32. Kohn, W. \& Sham, L. J. Self-consistent equations including exchange and correlation effects. Phys. Rev. 140, A1133 (1965).

33. Kresse, G. \& Hafner, J. Ab initio molecular-dynamics simulation of the liquidmetal-amorphous-semiconductor transition in germanium. Phys. Rev. B. 49, 14251-14269 (1994)

34. Blöchl, P. E. Projector augmented-wave method. Phys. Rev. B. 50, 17953 (1994).

35. Perdew, J. P., Burke, K. \& Ernzerhof, M. Generalized gradient approximation made simple. Phys. Rev. Lett. 77, 3865 (1996).

36. Jain, A. et al. Commentary: the materials project: a materials genome approach to accelerating materials innovation. APL Mater. 1, 011002 (2013).

37. Momma, K. \& Izumi, F. VESTA 3 for three-dimensional visualization of crystal, volumetric and morphology data. J. Appl. Crystallogr. 44, 1272-1276 (2011).

\section{Acknowledgements}

This work was supported by the U.S. Department of Energy (DOE) through ARPA-E Grant DEAR0000389.

\section{Author contributions}

L. Chen designed the experiments and analyzed data. X.J. conducted the calculations. L. Chen, L. Cao, X.J., S.H., Q.L., J.C., C.Y., and N.E. conducted experiments. C.W. conceived and supervised the project. All authors contributed to interpretation of the results. L. Chen and L. Cao contributed equally to the paper.

\section{Competing interests}

The authors declare no competing interests.

\section{Additional information}

Supplementary information is available for this paper at https://doi.org/10.1038/s41467 020-16460-w.

Correspondence and requests for materials should be addressed to C.W.

Peer review information Nature Communications thanks the anonymous reviewer(s) for their contribution to the peer review of this work.

Reprints and permission information is available at http://www.nature.com/reprints

Publisher's note Springer Nature remains neutral with regard to jurisdictional claims in published maps and institutional affiliations.

Open Access This article is licensed under a Creative Commons Attribution 4.0 International License, which permits use, sharing, adaptation, distribution and reproduction in any medium or format, as long as you give appropriate credit to the original author(s) and the source, provide a link to the Creative Commons license, and indicate if changes were made. The images or other third party material in this article are included in the article's Creative Commons license, unless indicated otherwise in a credit line to the material. If material is not included in the article's Creative Commons license and your intended use is not permitted by statutory regulation or exceeds the permitted use, you will need to obtain permission directly from the copyright holder. To view a copy of this license, visit http://creativecommons.org/ licenses/by/4.0/

(C) The Author(s) 2020 